\title{
WAITANGI, TRANSLATION, AND METAPHOR
}

\author{
Richard Dawson ${ }^{1}$
}

\begin{abstract}
The paper directs attention to and criticizes an unexamined metaphor that dominates talk about the translation of the Treaty of Waitangi. Key terms in the Treaty, such as 'Sovereignty' and 'Property', are commonly talked about as if they point to entities in the world, observable by us independently of the talk about them. The activity of 'translating' the Treaty, in this schema, is talked about in terms of 'conveying' bits of meaning over from English to Maori, ultimately replacing one set of labels with another. Treaty translator Rev. Henry Williams has been repeatedly judged, implicitly or explicitly, something of a failure in his supposed task of 'conveying' cum re-labeling meaning. But meaning, I submit, is always meaning to someone, who is uniquely located in some context. What the Treaty means to one person, with their particular set of experiences and expectations, will of necessity be in some degree different from all others. Justly judging Williams requires that we let go of the 'conveying' metaphor. A new metaphor may enable us to see the Treaty and Williams quite differently; it may stimulate new questions and create new understandings.
\end{abstract}

'On the 4th of February, about 4 o'clock p.m.', Rev. Henry Williams wrote in his Early Recollections, 'Captain Hobson came to me with the Treaty of Waitangi in English, for me to translate into Maori, saying he would meet me in the morning at the House of the British Resident, Mr. Busby; when it must be read to the chiefs assembled at 10 o'clock.'2 It has often been expressed or implied that Williams' translation of the Treaty into Maori is unfaithful to the English text. Many of his critics, however, use and talk about the words in the Treaty texts as though they contain solid meanings, like the way furniture resides in homes - securely 'there' where a reader can see and grasp them the way we can see and grasp tables and chairs. ${ }^{3}$ This view of words is associated with a view of a translator as someone akin to a furniture remover, who picks furniture (meanings) up from one home and transports it to another home. In terms of 
this furniture analogy, some critics imply that Williams failed to deliver all the furniture, or that he damaged the furniture in the act of conveying, or that he replaced some of the furniture with different furniture.

Roots of this language for talking about objectified meanings may be traced through Thomas Hobbes, a founding philosopher of modern Western civilization. In his 1651 book Leviathan Hobbes tells us of the Garden of Eden as a place where Adam is said to have spoken a language in which one word conveyed the root meaning of one thing, without the possibility of confusion. This language, he says, was 'lost at the tower of Babel, when by the hand of god, every man was stricken for his rebellion, with an oblivion of his former language. ${ }^{4}$ The fall of the tower marked the beginning of a complete communicative breakdown. Hobbes apparently saw linguistic diversity and the inevitability of mutual misunderstanding as elements of a punishment for pride, particularly the belief that human beings might reach heaven, and therefore immortality, without the journey through death. The damage could only be undone, Hobbes thought, by creating a new language, its concepts strictly and 'scientifically' defined. ${ }^{5}$ In thinking the damage could be undone, Hobbes appears to have inferred language could function as a transparent tool for pointing to something. If language could function this way, all thought could be reduced to a kind of calculation. Language thus could be a kind of mechanism, a closed system of mutually adapted parts working together as in a machine.

Various people who have resisted such a view suggest language is non-mechanistic in character, with interdependencies between words (and other nonverbal signs) that are complex and contextual. ${ }^{6}$ Language, in this view, is a living cultural artifact that shapes both who we are and our perceptions of the world. A revised story of Babel incorporating this view of language is as follows. The tower may have been destroyed in order to open the human mind to the appreciation of possibility. The confusion of language, by making it difficult for one group to communicate with another, permitted each group to develop relatively autonomously the possibilities inherent in the language it received. The development of a particular language over time is a cultural tradition, a tradition that is diverse, as expressed in numerous competing dialects and as found in verbal tensions between the rulers and the ruled and between groups or classes of many kinds. Each developing language is constituted by, expresses, and reproduces a particular intelligibility. ${ }^{7}$ Since each language represents only one of many possible understandings, we can never fully understand a communicative act, not even one of our own. We can, however, seek a deeper understanding through a meeting of languages. Here we can experience what has been called the 'misery' and the 'splendour' of translation, an 
experience on offer not just for those translating between languages but for anyone engaged in a communicative act. ${ }^{8}$ The misery of translation resides in the impossibility of restating the meaning of an utterance, because of irreducible differences between languages and people. The splendour of translation is its engagement with these differences. The engagement may be thought of as a shared journey where the differences between languages and people can be more fully seen, and thereby enabling them to be better understood.

With a view to promoting the splendour of translation in Waitangi discourse, this paper directs attention to the dominance of a way of imagining the Treaty that conceals the misery of translation.

A story suggestive of the misery and the splendour of translation may be helpful here. The following story is about an attempt to translate common legal terms into Chinese:

Imagine an American lawyer visiting the court of the emperor of China in 1800 . Through a Mandarin translator, he starts to tell the emperor that he is a lawyer, only to be informed by the translator there is no word in Mandarin for 'law.' The closest approximation is the word $f u$, meaning 'punishment' or 'sanction.' Thus, if the translator described the American as one who practices $f u$, the emperor would assume that he was a judge, one who administers punishment.

The American is encouraged to learn that at least the emperor has a word for 'judge,' but the translator quickly informs him that a better translation for the title of the Chinese official who administers $f u$ would be 'magistrate, because such officials exercise administrative as well as judicial functions. The American then asks the translator if there is a word for a person who assists those appearing before a magistrate. The translator replies there is, song-gun, but suggests against using the word because it is a term of scorn, perhaps similar to the word 'shyster.' He explains to the puzzled American that in Chinese 'courts' the parties always represent themselves. Illiterate persons often employed the services of a scrivener, but these scriveners were generally prohibited from giving advice or trying to influence the magistrate's decision. A scrivener who ignored such prohibitions was called a song-gun. Thus there is no word for a pro- 
fessional court advocate, and indeed no noun 'advocate.'

The translator asks the American to explain what exactly a lawyer would do in court. The American suddenly decides to use the translator himself as an example, saying that as he helps the lawyer explain to himself to the emperor, so too the lawyer helps his client explain his case to the judge. The language gap between the speakers of different languages is thus bridged by a common experience: the event that the emperor and the American are sharing at the very moment....

This exercise in translating 'lawyer' might lead the American, the Chinese translator and, through him, the emperor to a new understanding of what happens in their respective 'law courts', by suggesting the gap between the language used by the parties and the language used by the judge might be large enough to use the services of a 'translator,' even though both might have previously assumed that everyone in their respective courts was speaking the 'same language,' either English or Mandarin. ${ }^{9}$

In this story we see a lawyer and a translator engage with differences between languages and peoples. At first they identify linguistic differences between two peoples: a 'language gap' exists, for a word-for-word translation is seen to be impossible. A moment of mutual understanding was achieved (differences were 'bridged') through the imaginative invention of a metaphor, namely the lawyer as translator, to highlight a 'common experience.' This joint process of coming to a moment of mutual understanding came about through two steps. First, the translator constructively asked the lawyer about the activity of being a lawyer (about what 'a lawyer would do in court'); second, the lawyer constructively imagined the activity of the lawyer to be one similar to that of the translator. The exercise in translating 'lawyer', as the storyteller says, may lead the lawyer and the translator and any others who hear about the exercise to a 'new understanding' of what 'law' is all about. This 'new understanding', I suggest, is not the acquisition of inert knowledge but a shift in the way one imagines and thus experiences the world, and the self and others in it.

Shared understanding, in any language, is a matter of degree. Miscommunication may be reduced in degree by effort and interaction. Communicants with significantly different backgrounds may find achieving a high degree of mutual understanding to be a very difficult process. Such understanding requires the communicants to become aware of the differences in their respective 
backgrounds. In order to do so the communicants need to invent metaphors to communicate the relevant parts of unshared experiences or to highlight shared experiences. ${ }^{10}$ In this joint process of giving meaning to experiences the communicators co-evolve. The process is one of reciprocal change.

Viewing meaning as an experiential process may be thought of as a preliminary toward establishing an egalitarian community; a space is made for learning through conversation. When we acknowledge we do not fully or completely understand then conversation can begin. Communication involves not just the movement of information between one person and another but the process of constituting one kind of community or another between them. ${ }^{11}$

James Boyd White, in his 1990 book Justice as Translation, gave much attention to relational aspects of translation. Interested in how we might conceive of and talk about the processes of translation, White developed the metaphor of the dance:

We can think of an expression ... not as a way of conveying a message or idea, as a 'vehicle' with a 'content,' but as a gesture the meaning of which is indissolubly tied to its immediate and unique context: to its language and culture, to the social relations out of which it emerges and upon which it acts, to the prior texts that its author and audience use to establish and understand its terms, to its location in a particular place in the physical world, and so on. Our responses to such expressions, whether interpretations or translations, are not to be thought of as replicating the originals or conveying their 'content' but as gestures themselves; as if the first expression were a piece of a dance, an invitation to make a dance together, and as if our response to it were answering movements. There is to such a gesture no single right response but an infinitude number of possible responses, many of them good ones, many not so good; in evaluating them we should not speak of accuracy so much as appropriateness. ${ }^{12}$

Failure in the effort to fully reproduce meaning can be instructive to the extent that 'it brings one to a sense of self and language that is different from, and erosive of those that guide our initial expectations. ${ }^{33}$ Failure enables one to discern that one's own mind is institutionalized, that is, a product of culture. By becoming conscious of ways in which culture shapes the mind one develops an understanding of the self: 'To the extent that we speak and act (however confidently) through inherited forms upon which we do not reflect, we may only seem to have identities or voices of our own, not actually have them. ${ }^{14}$ 
There is a sense, White suggests, in which the activity of translation can be a model for social life:

It recognizes the other - the composer of the original text - as the center of meaning apart from oneself. It requires one to discover both the value of the other's language and the limits of one's own. Good translation thus proceeds not by the motives of dominance or acquisition, but by respect. It is a word for a set of practices by which we learn to live with difference, with the fluidity of culture and with the instability of the self. It is not simply an operation of mind on material, but a way of being oneself in relation to another being. ${ }^{15}$

The matter of 'relation' is central here. 'Who are we to each other?' This is the question, suggests White, two negotiating heads of state ask, whether they know it or not, when they work out an agreement, say about arms reduction, expressed in Russian and in English. This question about relations is the material of justice talk. In such talk we ask something like this: What place to stand is there for me in your world, and for you in my world?

On 6 February 1840 at Waitangi, just before the chiefs present were first asked to sign the Treaty, William Colenso, an employee at the printing-office of the Church Mission at Paihia, expressed concern about the addendum to the Treaty, which stated that the Chiefs had been made 'fully to understand the Provisions of the foregoing Treaty. ${ }^{16}$ Colenso recorded this:

\section{Colenso:}

May I ask your Excellency whether it is your opinion that these $\mathrm{Na}-$ tives understand the articles of the treaty which they are now called upon to sign?

\section{Hobson:}

If the Native chiefs do not know the contents of this treaty it is no fault of mine. I wish them to fully understand it. I have done all that I could do to make them understand the same, and I really don't know how I shall be enabled to get them to do so. They have heard the treaty read by Mr. Williams.

\section{Colenso:}

True, your Excellency; but the Natives are quite children in their 
ideas. It is no easy matter, I well know, to get them to understand - fully to comprehend a document of this kind; still, I think they ought to know somewhat of it to constitute its legality. I speak under correction, your Excellency. I have spoken to some chiefs concerning it, who had no idea whatever as to the purport of the treaty. ${ }^{17}$

The language used in this exchange between Colenso and Hobson images the Treaty to be like a container, for it has 'contents.' The contents are words, which are implied to hold meanings or 'ideas', which are like inert objects that can be picked up and transported without change to another place. To understand the text supposedly involves being able to grasp the meanings in the words, that is, to take in an object into the mind. (The word 'comprehend' used by Colenso is from the Latin com + prehendre, 'to grasp together'.) Failure to achieve complete mutual understanding, for those who live by the metaphor of understanding is grasping, emanates from a communication blockage, the responsibility for which resides with either the sender or the receiver or both. Hobson seems certain that he himself is not responsible: 'If the Native chiefs do not know the contents of this treaty it is no fault of mine.' Colenso's claim that 'the Natives are quite children in their ideas' implies that the 'Natives' are the source of the blockage, perhaps lacking the minds with the capacity to unpack the meanings in the words or to arrange the meanings in the correct order. When translation is involved, as is the case with the Treaty, in situations of disagreement about meaning, it is common for accusations to be made about the competence and/or faithfulness of the translator.

Colenso's and Hobson's pictures of understanding a text and of what constitutes mutual understanding are made up of a constellation of metaphors, some of which may be summed up as follows. A text is a container; words are containers; meanings are objects; understanding is grasping; communication is conveying; the mind is a machine. ${ }^{18}$ A great deal of Treaty law talk is heavily influenced by this constellation of metaphors, though these seem to be unrecognised as such. Becoming conscious of these metaphors, I suggest, would be a part of a movement toward higher degrees of self-understanding. And such a movement is an important requirement for achieving higher degrees of mutual understanding. Conversation is what is necessary for such a movement to take place.

Greater degrees of mutual understanding, as I have said, may be reached through the invention of metaphors. This point brings to mind Nopera Panakareao's speech on 28 April at Kaitaia, during Treaty negotiations. The Te Rarawa leader's speech, in my view, offered possibilities for conversation, one 
that may have undermined the image of the Treaty as a container of meaning. Translated notes written by observers of the speech are as follows:

Hear, all of you, Pakehas and Mouris [sic]. This is my speech. My desire is that we should all be of one heart. Speak your words openly ... I am at your head. I wish you to have the Governor ... My grandfather brought the Pakehas to this very spot, and the chiefs agreed with what my grandfather did. He went on board the ships and got trade. He spread it through the land. Let us act right, as my ancestor did. The Pakehas went to the Bay of Islands, and were murdered. Let us do them no harm. What has the Governor done wrong? The shadow of the land goes to Queen Victoria, but the substance remains with us. We will go to the Governor, and get a payment for our land, as before. If the Naponi [sic] commit evil they will suffer. We have always been friendly with the Pakehas. We never went in ships to England or Port Jackson to buy arms to kill our countrymen...Live peaceably with the Pakehas. We have now a helmsman. One said 'let me steer,' and another said 'let me steer,' and we never went straight ... What man of sense would believe that the Governor would take our goods, and only give us half of it. If you have anything else to say, say it; but if not, finish; and all of you say yes. Say yes. ${ }^{19}$

The sentence referring to 'shadow' and 'substance' evidently was an attempt to connect the Sovereignty/Kawanatanga Clause and the Property/Rangatiratanga Clause and to connect them to a phenomenon he and others were all familiar with, namely, a shadow. I know of no evidence to indicate that the Queen's representatives communicated with Panakareao about this imagery.

The two terms 'kawanatanga' and 'rangatiratanga' were used in the $1835 \mathrm{~A} \mathrm{Dec}$ laration of the Independence of New Zealand, which Panakareao signed, and which Williams translated. The term 'Rangatiratanga' was used for 'Independence' and the term 'Kawanatanga' was used in the Declaration's Sovereignty Clause. ${ }^{20}$ The 'Sovereignty' of the Declaration differs from the 'Sovereignty' of the Treaty if only because it is being used in a different context. Unlike the Declaration, which is made by one party proclaiming autonomy with respect to territory against all others, the Treaty is an interchange involving relations between parties.

What was the character of these relations? It seems to me that this is a ques- 
tion Panakareao was responding to when he came up with his metaphors. The texts of the Treaty are silent on a number of issues, including details on the administration of governance. Important distinctions are absent: key interrelated terms such as 'sovereignty', 'kawanatanga', 'property' and 'rangatiratanga' are not talked about in terms of mutually limiting and defining capabilities. (The absence of such distinctions generally go unnoticed by those who live by the image of understanding is grasping, for it is the words themselves that supposedly contain meaning.) There is nothing in the texts concerning the specific terms by which the coexistence is to be structured or even talked about. ${ }^{21}$

Panakareao's reading of the Treaty suggests to me that the parts of the Treaty should not be read in isolation from each other. If we accept that the whole of a text cannot be divided into parts and treated independently of the whole then it will be accepted that we have no absolute starting points and no selfevident certainties on which we can build a reading of it. Many readings, all of which may be well reasoned, can be expected. With such readings we have the material for the splendour of a good conversation, which is the material of misery for those wanting objective meanings.

Soon after the Waitangi negotiations, hostilities emerged between and within tribes over relative capacities to sell land. The Governor frequently contributed to the emergence of these hostilities. In January 1841, Panakareao reversed his saying relating to the shadow and substance. A translation of his reversal reads: The substance of the land goes to the Europeans, the shadow only will be our portion. ${ }^{32}$ In 1856, just before he died, an elderly Panakareao offered this imagery in relation to his metaphor of sovereignty as shadow: 'What truly is a shadow? It is like death that the hand cannot hold. ${ }^{23}$ Panakareao here appears to have come to a greater appreciation of the limits of language.

In the 1850 s, a number of chiefs sought to promote a pan-tribal authority with a view to re-establishing peace. In 1858, Potatau Te Wherowhero was installed as the Maori King. From the first news of the emergence of this institution, Governor Thomas Browne, along with many settlers, took the view that the existence of the King undermined or demeaned the authority of the Queen. Co-existence on terms mutually agreed upon was, for Browne, not an option. For Browne to constitute his own self as that of an equal with a chief probably was difficult; he was disposed to engage in absolutist talk with them. Consider, for example, this solar metaphor of his: 
Are there two suns in the heavens? Can there be two sovereigns for New Zealand? Queen Victoria is the Sovereign of this Island and all its inhabitants are Her Subjects. ${ }^{24}$

Browne only had to look to the United States of America, where there were multiple 'sovereigns': there was talk of the 'sovereignty' of state (and tribal) governments and of the federal government. Each government was 'sovereign' in particular spheres of activity. In situations of conflict between the 'sovereigns' arising from interdependencies, the critical issue concerned the relative scope of each sphere.

In May 1861, Browne issued a Proclamation to 'the Natives Assembled at Ngaruawahia' deeming the activities of the King to be 'inconsistent with allegiance to the Queen, and in violation of the Treaty of Waitangi'. He presented himself as following orders: he 'had been commanded by Her Majesty the Queen to suppress unlawful combinations, and to maintain Her Majesty's sovereignty in New Zealand.' Browne went on to state:

Submission to her Majesty's Sovereignty requires ... that every man yield ... obedience to what the Law (which is the same for all) prescribes for the public welfare ... Whenever the Maories forfeit [the protection of the Treaty], by setting aside the authority of the Queen and the Law, the land will remain their own so long as they are strong enough to keep it: - might and not right will become their sole title to possession. ${ }^{25}$

In refusing to enter into conversation with the King, Browne refused to open up himself, or at least his solar metaphor, to refutation. This refusal brought into being an authoritarian community.

In 1862, an elderly Henry Williams, whose health was beginning to deteriorate, was critical of Browne's actions in private correspondence; he evidently did not have the capacity to participate in public debate, perhaps to argue that Browne's actions were unfaithful to the Treaty interchange. ${ }^{26}$ Browne, in my view, had lifted the Sovereignty Clause from the Treaty and inferred that it had a plain meaning, neglecting the fact that it is part of a larger whole. Such a way of reading may be called 'reading by disintegration. ${ }^{27}$ This way of reading was instrumental in rationalizing the activity of cultural disintegration, more commonly known as assimilation. 
In the late 1860 s the matter of the control of the Kauwaeranga foreshore became the center of a dispute between Ngati Maru and Crown officials. In 1869, two years after Williams' death, in order to address the issue of the tribes' 'rights', Walter Mantell, in the Legislative Council, requested that the English text of the Treaty be translated into Maori, since the original was said to be in execrable Maori. ${ }^{28}$ No reason is given for such a description. Williams was not around to defend this arbitrary censure, and no one evidently sought to defend his name. An employee of the Native Department, Thomas Young, carried out the translation. ${ }^{29}$ The original use of 'kawanatanga' for 'sovereignty' in the first article was not followed: the words 'mana' and 'Rangatiratanga' were used instead. Also, Young's construction of the second article replaced Williams' 'rangatiratanga' with 'tuturutanga', a word suggesting something like 'permanence. ${ }^{30}$ I have not been able to locate any information on what Mantell thought of Young's translation. Was this also 'execrable Maori'? What was the difference between Williams' text and Young's text? It seems to me that both texts can be given widely different readings with regard to the matter of who can do what to whom. Neither Williams' text nor Young's text speaks for itself. Both texts are silent on who should participate in reading it at the level determining whose claims should count at law. People speaking in the name of 'the Crown' filled this silence with their own voice, without making a place for the voice of the Other.

In 1922, the Hon. Sir Apirana Ngata, who had held the Eastern Maori seat in Parliament since 1905, wrote an essay entitled: Te Tiriti o Waitangi: He Whakamarama, which was translated into English by M. R. Jones, with the subtitle rendered as An Explanation. Ngata's way of reading, by disintegration, imitated that of Crown officials. He treated each clause as separate entities. This is what he had to say on the Rangatiratanga Clause:

[T]here are several words in the English version which were not adequately rendered into the Maori language. This is my translation:

'Ko te Kuini o Ingarangi ka whakapumau, ka whakaoati kia whakatuturutia ki nga Rangatira, ki nga Hapu o Nui Tireni, a ki ia whanau, ki ia tangata ranei o ratou, te mana te rangatiratanga o o ratou whenua, o o ratou ngahere, o o ratou taunga-ika, o era atu taonga ranei a ratou, a ia tan- 
gata ranei o ratou mo te wa e hiahia ai ratou ki te pupuri i aua mea;...'

This is the article from which stems the matters which are discussed throughout the maraes in regard to the Treaty of Waitangi. When a bad law is made it is said to contravene the Treaty of Waitangi. The Government confiscates the land, it is said this is wrong, because it contravenes the guarantee of the Queen under this article of the Treaty. This has given rise to wishful thinking on the part of many Maori groups, for the formation of Absolute Maori Authorities, variously called Kotahitanga (United Group) Kauhanganui (Open Forum) Maori Parliament or other designations. All this wishful thinking goes back to this article in the Treaty. Indeed these ideas were due to confusion as to the authority of the Maori that was set out in the first article of the Treaty.

What is this authority, this sovereignty that is referred to in the second article? It is quite clear, the right of a Maori to his land, to his property, to his individual right to such possessions whereby he could declare, 'This is my land, there are the boundaries, decended from my ancestor so and so, or conquered by him, or as the first occupier, or so and so gave it to him, or it had been occupied by his descendants down to me. These properties are mine, this canoe, that taiaha (combination spear and club), that greenstone patu (club), that kumara (sweet potato) pit, that cultivation. These things are mine and do not belong to anyone else. ${ }^{31}$

But what if a 'Maori' claims some piece of land as 'his property' and someone speaking in the name of 'the Crown' cum 'sovereign' disputes this claim? A war was fought over such a situation, and Ngata fails to address it. ${ }^{32}$ Such a failure reflects his disintegrated reading of the Treaty, disintegrated in the sense of failing to link the different parts.

When Ngata wrote his 'explanation' he was involved in a claim over the 'ownership' of the foreshore and Te Arawa was involved in a dispute with 'the Crown' over the ownership of Lake Rotorua and adjacent lakes. He framed the issue as follows. He stated that there is 'one part' of article two that is 'not quite clear, the part about the fishing grounds together with the fresh water lakes, the mud flats, pipi beds and oyster rocks.' In his translated words:

Article two states that 'The Treaty guarantees to the Maori people 
their rights and possessions to their lands, their forests and their fisheries.' There is no doubt about the lands and forests. But the part in doubt is that which concerns the lakes situated amidst all the land, the mudflats, that is, the lands which become submerged by sea water at high tide. To the Maori these lands belong to him and that is why he considers his rights to these should be established under Article Two of the Treaty. However, ... Article Three of the Treaty gave to New Zealand British laws which became effective on the signing of the Treaty and conform with 'all the rights and privileges of British Subjects'.

British law states that the sea from high water mark to a point three miles out belongs to the Crown. The mudflats, the pipi beds, the oyster rocks and the fishing grounds are all below high water mark. These are conflicting points that have been left in doubt. The voice of Parliament has in no way indicted any legislation which would establish in us ownership of these possessions of our ancestors.

The Arawa case concerning its fresh water lakes is still before the Courts and whether it will be decided there remains to be seen; the case might very well be settled out of Court between the people and the government. ${ }^{33}$

Not once does Ngata question the authority of the then existing constitutional arrangements, for determining the meaning of the Treaty in the context of disputes over who can do what to whom.

At the end of his discussion on the Rangatiratanga Clause Ngata offers his reader some words on Panakareao's words:

These are the words of Nopera Panakareao, a Chief of the Rarawa when a copy of the Treaty reached Kaitaia for Te Rarawa and Aupouri Tribes to sign: 'It is the shadow of the land which had been given to the Queen while the soil remains.' These are very wise words, an old time saying. The saying of the elderly chief has combined the words of the first article with those of the second article of the Treaty. It is the shadow, that is, the main authority covering the land; it is the power to make laws, the power to say this group shall adjudicate, that authority should see that the purchase is right, while that one leads the individual through the main intricacies of the law, that was the shadow ceded to the Queen by the first article 
of the Treaty. As for the soil, it is yours, it is mine inherited from our ancestors. It was the second article which firmly established this to the Maori people. ${ }^{34}$

Ngata here began by identifying Panakareao's effort to address the character of the relationship between the two articles ('has combined the words of the first article with those of the second'), but he did not pose and address any questions that might flow from the effort. Let me do this. Can the sovereign 'shadow' determine who has what soil 'substance'? Is the 'shadow' the 'substance'? What, following Panakareao, is this 'shadow'? Such questions, in my view, are really about the limits on a sovereign's 'power to make laws.' Ngata failed to address such questions, probably because of the force of the mindset that the 'sovereign' is not limitable. Such a mindset may be a comfortable one for those who do not wish to talk, especially to those who are disposed to merely 'wishful thinking.'

Published in 1972, when the roots of what has come to be known as the 'Maori Renaissance' were forming, Ruth Ross' essay Te Tiriti o Waitangi: texts and translations made an incriminating case against translator Williams. Much of her case rests on the term 'mana'. In a section on the first article she invokes her 'experts':

In 1869, when the Legislative Council ordered a 'careful translation' of 'the English version', T. E. Young of the Native Department translated 'all the rights and powers of sovereignty' as nga tikanga me nga mana katoa o te Rangatiratanga. Sir Apirana Ngata's twentiethcentury explanation of the treaty leaves no doubt that in his view te mana rangatira, chiefly authority, had been ceded to the Queen by the Treaty of Waitangi. To all these experts the Maori concept of mana was part of the European concept of sovereignty, but in the Treaty of Waitangi there is no mention at all of mana. ${ }^{35}$

It seems to me that there are considerable dangers associated with talk about the word 'concept', in this case the 'concept of mana' and the 'concept of sovereignty'. Ross takes a step here towards looking at things as if they are independent of language. Ross images 'the European concept of sovereignty' as an entity that has parts, and one of which links in or is equivalent to 'the Maori concept of mana'. On this view, the function of words is to define concepts that are thought to exist outside language and beyond culture. ${ }^{36}$ This image 
is associated with the metaphor of understanding is grasping. Implicit in the talk associated with this metaphor is the claim that concepts can be wholly restated in various languages. Such a view readily becomes imperialistic in character, for there is no reason why we should learn more than one language. ${ }^{37}$

Ross' arguments are largely built on her identification and interpretation of precedents for particular usage of terms. She says this about the term 'kawanatanga' - 'a coined word, from kawana, itself a transliteration of "governor"':

The word kawanatanga had been in occasional use in mihinare translations since 1833 in the order for morning service: 'that all our doings may be ordered by the governance' - ki tou kawanatanga; and in 1 Corinthians 15:24: 'Then cometh the end, when he shall have delivered up the kingdom of God, even the Father; when he shall have put down all rule and all authority and power' - Ko reira te mutunga ino oti te rangatiratanga te ho atu e ia ki te Atua te Matua; ina oti te w[h]akangaro te kawanatanga katoa, te mana katoa me te kaha.

Had Williams applied this scriptural precedent and associated mana with kawanatanga in the translation of sovereignty, no New Zealander would have been in any doubt about what the chiefs were ceding to the Queen. There was, moreover, already a precedent in a secular political context for including mana in the translation of sovereignty. In the Maori text of Busby's declaration of independence, all sovereign power and authority within the territories of the United Tribes' was translated as ko te Kingitanga ko te mana o te $w[h]$ enua o te $w$ [h] akaminenga. Yet when this same sovereign power and authority was to be ceded to the Queen by, among others, the very chiefs who had supposedly declared themselves possessed of it in 1835 , only kawanatanga katoa of their lands was specified. It is difficult not to conclude that the omission of mana from the text of the Treaty of Waitangi was no accidental oversight. ${ }^{38}$

Ross here is reading the Treaty by disintegration, ignoring the fact that its parts are linked to a whole. In ceding 'sovereignty', what was ceded? One's response to this question will depend on, among other things, what sense one makes of the other parts of the Treaty, such as the meaning of the word 'undisturbed' in the Property Clause. Ross simply failed to talk about relations between the parts and their influence on meaning. Had Ross thought to talk about these relations between the parts, she may have noticed a basic and 
significant difference between the Declaration and the Treaty, thereby undermining the authority of what she claimed to be an apt precedent.

The difference I have in mind is as follows. The matter of the limits to the powers of the Declaration's 'sovereign' was not an issue for those who signed it, for it did not seek to establish a functioning set of laws for managing relations between the chiefs and non-chiefs. Not so with the Treaty: the existence of the Property Clause brings to the fore the issue of limits to the powers of the Treaty's 'sovereign'. Contrary to Ross, I submit that the 'sovereign power' of the Declaration and the 'sovereign power' of the Treaty are not 'the same'.

Ross' fragmented reading of the Treaty continued with her commentary on the term 'rangatiratanga'. She again cites precedent:

The document signed in October 1835 by thirty-four Bay of Islanders and subsequently by a number of other chiefs entitled $\mathrm{He}$ $w$ [h]akaputanga o te Rangatiratanga o Nu Tireni, supposedly a 'declaration of independence' of New Zealand. Was it 'independence' which the Queen guaranteed to the chiefs, to the tribes, to all the people of New Zealand in 1840 ? In missionary Maori, rangatiratanga was 'kingdom': te rangatiratanga o te Atua -- the kingdom of God; tuka mai tou rangatiratanga -- thy kingdom come; ehara taku rangatiratanga $i$ tenie ao -- my kingdom is not of this world. But in a proclamation issued on 27 April 1840 in which Hobson warned the chiefs that a certain evil Pakeha had been stirring up trouble against te rangatiratanga o te Kuini, the word rangatiratanga was used to denote 'sovereignty'. Was it any wonder that the New Zealanders at first supposed the Queen had guaranteed them something more than the possession of their own lands? At least one chief, Nopera Panakareao of Kaitaia, soon realised his mistake. In April 1840 he had supposed that the shadow of the land would go to the Queen, 'but the substance will remain with us'. By January 1841 he was already apprehensive that the substance would go to the Queen and 'the shadow only' would be the New Zealander's portion. ${ }^{39}$

Contrary to Ross, the chiefs in fact were guaranteed 'something more than the possession of their lands', namely, full exclusive and undisturbed possession. But what does 'full exclusive and undisturbed' mean? Like 'substance', the meaning of this expression, in my view, is not transparent. Its meaning, in relation to, among other things, the Sovereignty Clause, had to be worked out, and the Treaty is silent on how this working out might be done. The physical 
force that filled the silence did not have to happen: a conversation was, and still is, a possibility.

Claudia Orange, in her 1987 book The Treaty of Waitangi, argued that ' $\mathrm{t}$ ]he [Maori] text failed to convey the meaning of the English version, and the treaty negotiations did not clarify the difference. ${ }^{40}$ When it came to talking about the Kaitaia meeting, she had the following to say about Panakareao:

Nopera, who had signed the earlier Declaration of Independence, believed that he had prepared carefully for the treaty meeting. On the previous evening he had questioned both the resident CMS missionary, William Puckey, and government officials about the treaty, in particular the word sovereignty. An attempt had been made to make it 'intelligible' to him. It became clear, however, that Nopera had failed to grasp the transfer of power and authority implied in the treaty. ${ }^{41}$

Contrary to Orange, a text does not contain a meaning that one can 'convey', we readers use a text to make meaning. I do not accept Orange's claim that Nopera 'failed to grasp the transfer of power implied in the Treaty'. Officials speaking in the name of the Crown acquired the power she speaks of through physical force some years after Panakareao died. The physical force used gave weight to Browne's 'sovereign as sun' metaphor, and this metaphor eclipsed Panakareao's 'sovereign as shadow' metaphor, a metaphor that the British negotiators did not quibble with in 1840. Orange's history lacks the historical sense in this regard; she looks for causation of human activity in preceding events rather than placing herself in the position of the participants and imagining what they expected when they acted. ${ }^{42}$ The participants in the making of history do so whilst moving into the void of time, a void filled by their imaginations, which produce and are fueled by metaphors. Orange neglects the process by which certain metaphors and certain meanings have privileged status. Evaluating this process, as I am doing now, is the material of justice talk.

\section{VIII}

Talking past each other in discussions about the Treaty may readily begin because interlocutors differ over what is referred to in the use of 'the Treaty'. David Williams made this point in a 1989 essay in a collection of essays put together by Hugh Kawharu, titled Waitangi: Maori \& Pakeha Perspectives of the 
Treaty of Waitangi. Williams' essay gave particular attention to 'the problem' of having 'two Treaties'. An excerpt from it reads as follows:

The fact that both the Maori and an English text are now statutorily recognized has forced judges and lawyers to try to understand the differences between the two. The first problem is that neither text is a translation of the other. The Maori text was a translation by the Revd Henry Williams of an English draft which historians assume has been irrecoverably lost .... It was not until 1869 that there was an official attempt to translate accurately an English text into Maori and a literal translation of the Maori text into English. The work was done by T. E. Young, a Native Department translator, and the outcome is excellent, compelling evidence of the second major problem with the two texts as we now have them - they do not convey precisely the same meaning. On the contrary, they differ markedly and in respect of the essence as to what was being agreed to. ${ }^{43}$

Williams here talks about 'meaning' as if it is an object like a moveable bit of furniture in a home, a bit that is ready for a furniture remover to come in and 'convey' to another home. In my view, the 'excellent, compelling evidence' Williams offers his readers will only be persuasive to those who live by the same metaphors as he does.

Focusing his attention on the first and second articles of the Treaty, Williams goes on to tabulate what he calls 'key discrepancies', which Young's translations 'highlight'. In his table he includes, '(i) Professor Kawharu's attempt at a reconstruction of the literal translation of the Maori text..., and (ii) material drawn from Sir Apirana Ngata's 'explanation of the Maori text in light of the English text'. His table is as follows: Id., p. 78 (macrons omitted)

Article 1 - what was being given up by the Maori to the Crown?

$\begin{array}{lll}\text { Maori Text } & \begin{array}{l}\text { Young Translation } \\ \text { te kawanatanga katoa }\end{array} & \begin{array}{l}\text { Kawharu Translation } \\ \text { the complete } \\ \text { government }\end{array}\end{array}$

English Text

all the rights and powers of sovereignty
Young Translation

nga tikanga me nga

mana katoa o te

Rangatiratanga
Ngata 'Explanation'

te tino mana, te mana rangatira 
Article 2 - what was the Crown's guarantee to the Maori in respect of their land etc.?

$\begin{array}{lll}\text { Maori Text } & \begin{array}{l}\text { Young Translation } \\ \text { te tino rangatiratanga }\end{array} & \text { Kawharu Translation } \\ \text { the full chieftainship } & \begin{array}{l}\text { the unqualified exercise } \\ \text { of their chieftainship }\end{array}\end{array}$

\begin{tabular}{lll}
$\begin{array}{l}\text { English Text } \\
\text { full exclusive and } \\
\text { undisturbed possession }\end{array}$ & $\begin{array}{l}\text { Young Translation } \\
\text { te tino tuturutanga }\end{array}$ & $\begin{array}{l}\text { Ngata 'Explanation' } \\
\text { te whakapumautanga }\end{array}$ \\
\hline
\end{tabular}

For Williams, a significant feature of this table is the appearance of 'rangatiratanga' in both articles. He goes on to ask: 'Was rangatiratanga over land given up, ceded, or was it confirmed and guaranteed?' To this question he responds: 'This is the nub of the problem of the two Treaties.' Summarising the nature and significance of 'the two treaties', Williams says:

The Maori text predicates a sharing of power and authority in the governance of the country between Crown and Maori. The English text is about a transfer of power, leaving the Crown as sovereign and Maori as subjects. Much of the Treaty's history has been bedevilled by the fact that Maori and Pakeha have been 'talking past each other. $^{34}$

Williams suggests that there is merit in using 'te Tiriti' when one is referring to the Maori text and using 'the Treaty' when one is referring to the English text. This distinction would certainly be helpful for avoiding some talking past each other. But I suggest that the distinction has limits. The official texts of the Treaty are distinct parts of a larger whole, one that includes negotiations at Waitangi and elsewhere. These negotiations are a part of what may be called 'the Treaty', for the images one has of the negotiations may well influence the sense one makes of the texts. Different images held by different people and by the same person at different times may well underpin different meanings generated whilst reading the texts, whether the readers are 'Maori' or 'Pakeha' or both or neither. Williams, like many other Treaty commentators, overlooks these differences in meaning.

Unlike Williams, I do not see a 'problem' with a translator employing the word 'rangatiratanga' for both 'sovereignty' (following Young) and 'full exclusive and 
undisturbed possession' (following Henry Williams). Indeed I think that using 'rangatiratanga' for both expressions is helpful to highlight the putative fact that the two are similar to one another in the sense that they both concern spheres of power, or capacities to do something in relation to some other party. The real question concerns the limits of these spheres. The process of working out the limits would be the process of defining the Crown's rangatiratanga and the Tribes' rangatiratanga. The process, perhaps needless to say, would never end, for there will always be new issues to address, not the least the revisiting of old issues as we come to see them in a new light. One aspect of both the Crown's rangatiratanga and the Tribes' rangatiratanga would be a capacity to participate in giving meaning to 'rangatiratanga' as new issues need to be worked out. This is a capacity to participate in a conversation, one that, by definition, would not be controlled by one party.

IX

Andrew Sharp, in his 1990 book Justice and the Maori, perpetuated mechanistic imagery for reading the Treaty. In the process of doing so, he revealed something of his academic ancestry:

[T] he English and Maori versions ... mean ... different things. To take an example: in 1840 legal English, 'sovereignty' meant the absolute and indivisible power to legislate, judge, and interpret the law; the absolute power to administer it, and to back up its requirements by force; the sole power to engage in foreign relations and thus to appoint and control diplomats and force of arms. But in missionary Maori, the linga franca of the Maori and missionaries, 'kawanatanga' did not indicate the status of having full sovereign rights of government. It rather indicated the delegated and limited rights of, say, the Roman Pontius Pilate in Israel - or of Hobson were he to become Governor: rights in Hobson's case delegated to him as much by the Maori as by his Queen. Such rights as he thus acquired would clearly not be those of a sovereign of a state or of a rangatira among his tribe. They would be limited - the Maori at Waitangi may well have thought - to keeping the peace by the use of force if necessary: to something like the derived merum imperium or ius gladii of the ancient Roman magistrate. Such peace-keeping activity they would have known about. Many Maori had traveled, for instance to New South Wales, and knew what governors were. Some had been the guests of governors and named their children after them. Many would have known what they were being offered 
because they had a concrete conception, derived from experience, of the kind of things governors did. But it is plainly impossible that they should have approached the abstract and magical conception of British legal sovereignty. To get near to it they would have had to have been told that sovereignty was like 'mana,' 'rangatiratanga', and 'kingitanga' - though impersonal, unlimited in its law-making scope and not obviously sacred. They would have had to have been told in the words of Thomas Hobbes, one of its greatest theorists, that the sovereign state was a 'mortal God': Leviathan, ruler of the proud, made by the proud to keep themselves in awe and to avoid bellum omnes contra omnium - the war against all. ${ }^{45}$

Sharp seems to me to be caught up in Hobbes' ideal world of the 'abstract' and the 'impersonal. We should in my view be concerned not with an abstract ' 1840 legal English' but, rather, with Hobson's 1840 English. To study this we must turn to his actual language, which includes, among other things, the English text of the Treaty. Hobson used the word 'sovereignty' in the Sovereignty Clause, which sits side-by-side with the Property Clause and other clauses, which are all parts of a whole composition, for which Hobson and his superiors are personally responsible for. What possible meaning might be given to the Property Clause if it does not place a limit on the power granted to the 'Sovereign' in the Sovereignty Clause? Sharp fails to ask this question, for he treats the Property Clause as separate and distinct from the Sovereignty Clause for the purpose of discussing 'meaning'.

Sharp stated that 'the Maori at Waitangi ... would have known about ... peacekeeping activity'. The activity of 'peace-keeping', like all activities, is a complex form of life that involves an experience that defies complete explanation, an experience that is not independent of culture. Sharp says that 'many Maori' would have 'had a concrete conception, derived from experience, of the kinds of things governors did.' What is 'a concrete conception'? And what is 'experience'? There may be said to be a fundamental interdependence between experience and perception, one that is mediated by culture and language, both of which are the product of experience and perception - a process of cumulative causation and infinite regress. ${ }^{46}$ By talking about 'experience' as if it can be reduced to a collection of words, which point to things, Sharp seems to ignore this complex interdependence.

Caught up in the 'abstract' and in a reduced form of 'experience', the material of reading by disintegration, Sharp seems to me to be closed off from what Panakareao, among other chiefs, might have been thinking and feeling in 1840 . 
In a 2002 essay entitled Bound into a fateful union: Henry Williams' translation of the Treaty of Waitangi into Maori in February 1840, Paul Moon and Sabine Fenton, made a particularly damning case against Williams, applying to him the Italian saying, 'traduttore, tradittore', 'the translator, a traitor., ${ }^{\text {' }}$ They provide evidence to suggest the influence of both 'patriotic motives' and 'private motives' in Williams' 'conscious mistranslation of key concepts of the Treaty.' Speaking generally on his approach to translating the Treaty, they write:

The convoluted and technical language of the English version is recast in simple Maori, but with strategic omissions. Moreover, certain crucial terms were not translated into the closest, natural Maori equivalent but into Maori words and concepts that were used to convey meaning in translations of the Bible, words and concepts which were generally understood differently by Maori or lacked any meaning at all. ${ }^{49}$

Moon and Fenton here perpetuate the use of the word 'convey' in their talk about meaning. The word 'concept' - and the related word 'notion' - is a central term in Moon and Fenton's discourse and they use it as if it is completely unproblematic. Like Ross, Moon and Fenton talk about the 'concept of sovereignty' as if the function of words is to define or clarify concepts that are thought to exist outside language and beyond culture. Consider the following excerpt, which is concerned with the Sovereignty/Kawanatanga Clause:

Kawanatanga was a missionary neologism based on the English word 'governor'... It had first appeared in early translations of the Bible, where Pontius Pilate was described as a kawana (Matthew 27:1-26). Not only was this word only partially familiar to the few Maori who had undergone missionary education, its context bore no direct relation to the notion of sovereignty. ${ }^{50}$

Moon and Fenton, who are caught up in the abstract world of 'notion', miss a similarity between a 'governor' and a 'sovereign', namely the existence of powers or capacities to do something in relation to another party. Identifying such a similarity offers an entry point for conversing about possible similarities and differences in the scope of the powers of a governor and of the powers of a sovereign. The relation between the Sovereignty/Kawanatanga Clause and the other clauses of the Treaty would be relevant to the conversation here. 
Moon and Fenton also have this to say on the Sovereignty/Kawanatanga Clause:

The other problem with the use of the notion of governor (in either English or Maori) was that there had never been a governor in New Zealand. Therefore there was no way in which the Maori signatories could have established the power and jurisdiction of such a person. The more appropriate word would have been mana, as used in the Declaration of Independence. Mana defies easy translation, but it can include power, prestige, authority and sovereignty. However, Williams bypassed this obvious choice, one with which he was familiar, and employed a far more ambiguous term. Even the handful of chiefs who might have been familiar with the Biblical concept of governor could never have equated ceding this unknown extent of authority to the Crown with the surrender of their mana. ${ }^{51}$

Concerning the 'problem with the use of the notion of governor', the 'Maori signatories' were not the only ones with the task of making sense of 'the power and jurisdiction of such a person. Hobson also had the task, for 'the power and jurisdiction' of this person in New Zealand would be limited by the Property Clause and the Rights Clause, the meanings of which are not transparent. Moon and Fenton, like Ross, fail to address this, for they are committed to a fragmented reading of the Treaty, treating the clauses as separate, independent entities. Had Moon and Fenton had their eyes less on thing-words and more on doing-words, so as to create a world of relations rather than objects, they may have been less inclined to talk about 'mana' as something the chiefs could 'surrender. ${ }^{52}$ Williams may well have 'bypassed' the term 'mana' simply because he imagined it as inappropriate for the context (unlike the Declaration).

Moon and Fenton have this to say on the Rangatiratanga Clause and on their view of Williams' relation to it:

Rangatiratanga - the power, rights and authority of the chief - was a sovereign power in its fullest sense. .... Williams' translation of the Treaty Article promised to the Maori signatories the same sovereignty that they were supposedly ceding under the First Article of the English version to the Crown. Consequently, ... Williams succeeded in ... carefully mutating the Maori version to make it palatable to the Maori chiefs, while appearing as a reasonable translation of the English version... . This formidable achievement, done 
with precision and care that no-one present at Waitangi on 5 and 6 February 1840 even noticed it, could only have been executed by someone who was extremely fluent in Maori and English. In both Article the First and Article the Second, the Maori text was cunningly manipulated to give the impression it was a competent translation of the English version of the Treaty. Yet, in the critical area of the transfer of sovereignty, Williams succeeded in devising, in the Maori text, a meaning that was fundamentally at odds with the English version. ${ }^{53}$

What is 'a sovereign power in its fullest sense'? Moon and Fenton fail to elaborate: they are engaged in abstract sovereignty talk, failing to talk about specifics, in the form of what the 'sovereign' can and cannot and may and must do. I see no difficulty with the term 'sovereignty' being used for 'rangatiratanga' and for 'kawanatanga'. Such use, as I suggested earlier, would make New Zealand resemble the United States of America, where there is talk of the 'sovereignty' of state (and tribal) governments and of the federal government. Each government is 'sovereign' in particular spheres of activity. The critical issue concerns the orbit of each sphere, an issue that cannot be worked out once and for all, for patterns of interdependencies are always in a process of becoming, due to changes in technology, economic circumstances, environmental conditions, values and attitudes.

The history of Waitangi translation discourse appears to me to be dominated by an unexamined metaphor. This metaphor commits its users to a particular view of meaning, namely, that it is like an object, such as a table, that can be picked up from the place that it stands and 'conveyed' to another place. Armed with this view of meaning, Treaty commentator after Treaty commentator directly or indirectly points the proverbial finger at Williams for causing the 'Treaty problems' of yesterday and today, for his failure to convey the object correctly.

Languages, in my view are products of ways of imagining the world, products that evolve as we use them, for reconstituting imaginings. If Hobson had had this view of languages, he would have asked questions like the following when he took responsibility for composing the English-language text of the Treaty. 'What do I think I mean in using the word 'sovereignty' here in this new context, with these peoples, and in association with the Property Clause and the Rights Clause? With what metaphors might I achieve a high degree of shared 
understanding with the Chiefs? With what metaphors might I achieve a high degree of shared understanding with the translator Williams, who may not read what I have written the same way I read it? What can I learn about the limits of my own language when learning what metaphors the Chiefs live by? What practices might I and the Chiefs create and put in place for managing differences over the interpretation of the Treaty?'

But Hobson evidently did not ask these questions. He probably said to Williams something like this: 'Here's the Treaty in English. Please translate it into Maori. See you in eighteen hours, when we will attempt to get the Chiefs to sign the Treaty.' It may well not have occurred to Hobson that his composition in English did not speak for itself. And it may not have occurred to Williams on 4 February 1840 that Hobson's composition did not speak for itself and that his own translation of it did not speak for itself.

One cannot, in my view, reasonably claim that when Williams performed his role as translator at Waitangi he could have remotely imagined that someone like Thomas Browne would come along and, in the name of the Queen, render the words of chiefs weightless. This rendering, it will be recalled, was rationalized with the invention of a solar metaphor, with a view to defining 'sovereignty' in a way that rationalized the use of force against the Maori King. The same may be said about Williams with regard to the performance of Young, who was asked to rewrite Williams' composition, presumably in order to legitimate the appropriation of the foreshore. Thinking about what Williams may and may not have imagined is, in my view, a necessity for acting justly toward him.

The flow of Treaty history could, quite easily, have been so very, very different. The beginning of a long conversation between the parties to the Treaty was possible had, say, the British negotiators at Kaitaia thought to question the merit of Panakareao's shadow and substance imagery. This may have prevented the practice of reading the various clauses of the Treaty in isolation from the other clauses and, thus, helped undermine the fallacy that meanings reside 'in' language like the way furniture resides in homes.

A conversation is still possible in $2005 .{ }^{54}$ What might become of Panakareao's shadow and substance imagery if those speaking in the name of 'the Crown' fall into conversation with officials of Te Rarawa about the meaning of his utterance? I hope that in asking this question I start a conversation. Doing justice, as I have suggested, begins in conversation. 
NOTES

1 The author is indebted to Dame Joan Metge for a number of very helpful comments on two drafts. The usual disclaimer applies.

2 Quoted in Ross 1972, p. 133.

3 Graff, 1982, has inspired this furniture imagery.

4 Hobbes, 1651 (1968), p. 101.

5 Id., p. 105.

6 Wittgenstein immediately comes to mind. See McCutcheon, 2001, for a relatively accessible introduction to Wittgenstein. Others who adopt a non-mechanistic view of language include Gadamer, 1975; Metge, 1976; Chaudhiri, 1998; Ortega y Gasset, 1937 and 1959; Robinson, 1997; Steiner, 1975.

7 This part of the Babel story draws from Hyland, 1990.

8 Ortega y Gasset, 1937.

9 Cunningham 1992, pp. 1336-8.

10 See Lakoff and Johnson, 1979, pp. 231-3.

11 For a discussion of different types of communities see Dawson, 2004.

12 White, 1990, p. 236.

13 Id., at 255 .

14 Id., at 260.

15 Id., at 257.

16 Familiarity with the Treaty is assumed here. Copies of the Treaty are now abundant, appearing typically as an appendix in a book on the Treaty, as in Orange, 1987.

17 Colenso, 1890, p. 38. 
18 In identifying and presenting these metaphors I have been heavily influenced by Reddy, 1979, and Winter, 2001.

19 Rev. Richard Taylor and John Johnson wrote the notes whilst listening to translator William Puckey. Source: British Parliamentary Papers, Colonies: New Zealand 2, pp. 58-9.

20 See the Appendices in Orange, 1987.

21 See Dawson, 2001, pp. 59-6o.

22 Quoted in Mutu, 1992, p. 17.

23 Id.

24 Quoted in Dalton, 1957, p. 46

25 Appendices to the Journal of the House of Representatives (1861), No. 1B, 11.

26 Fisher, 1991, p. 594

27 Tribe and Dorf, 1991, p. 22.

28 Orange, 1987 , p. 182

29 Orange, 1987, pp. 263-4, reproduces Young's work.

30 See Williams, 1989, pp. 78-9.

31 Ngata, 1922, pp. 7-8.

32 The incident I have in mind is the 'Waitara dispute', see Dawson, 2001, pp. 68-9.

33 Ngata, 1922, pp. 14-15.

34 Id., p. 8

35 Ross, 1972, p. 140 (footnote omitted).

36 See White, 1990, 29. 
Article $\cdot$ Dawson

37 Id., p. 31

38 Ross, 1972, pp. 140-1.

39 Id., pp.142-3, footnotes omitted.

40 Orange, 1987, p. 1.

41 Id., p. 82.

42 See Commons, 1934, p. 683.

43 Williams, 1989, p. 78.

44 Id., 1989, pp. 78-8o (footnotes and macrons omitted).

45 Sharp, 1990, pp. 17-18 (footnotes and macrons omitted).

46 See Samuels, 1990, p. 11.

47 Moon and Fenton, 2002, p. 61.

48 Id., p. 54.

49 Id., p. 57.

50 Id., p. 58.

51 Id., p. 58, citation omitted.

52 Metge, 1986, pp. 62-79, offers a helpful discussion on the term 'mana'.

53 Moon and Fenton, op. cit., pp. 58-9.

54 Metge, 2001, and Frame, 2002, advocate a conversational dynamic. 


\section{REFERENCES}

Chaudhiri, S. 1998 Translation and Understanding, Oxford: Oxford University Press.

Colenso, W. 1890 The Authentic and Genuine History of the Signing of the Treaty of Waitangi, Wellington: Government Printer.

Commons, J. 1934 Institutional Economics, New York: Macmillan.

Cunningham, C. 1992 The Lawyer as Translator, Representation as Text: Towards an Ethnography of Legal Discourse, Cornell Law Review 77: 1298-1387.

Dalton, B. 1967 War and Politics in New Zealand, 1855-1870, Sydney: Sydney University Press.

Dawson, R. 2001 The Treaty of Waitangi and the Control of Language, Wellington: Institute of Policy Studies.

Dawson, R. 2004 Linking Communication and Community: Communing in Witi Ihimaera's The Whale Rider, Management of Not-for-Profit Organisations Research Report Series: Waikato Management School.

Fisher, L. 1991 'Henry Williams', in (pp. 593-5) The Dictionary of New Zealand Biography, Wellington: Bridget Williams Books

Frame, A. 2002 Grey and Iwikau: A Journey into Custom, Wellington: Victoria University of Wellington.

Gadamer, H. 1975 Truth and Method, London: Sheed \& Ward.

Graff, G. 1982 'Keep off the Grass,' 'Drop Dead,' and Other Indeterminacies, Texas Law Review 60: 405-413

Hobbes, T. 1651 (1968) Leviathan, London: Penguin.

Hyland, R. 1990 Babel: a She'ur', Cardozo Law Review 11: 1585-612

Lakoff, G. and M. Johnson 1979 Metaphors We Live By, Chicago: University of Chicago. 
McCutcheon, F. 2001 Religion Within the Limits of Language Alone: Wittgenstein on Philosophy and Religion, Aldershot: Ashgate

Metge, J. 1976 The Maoris of New Zealand; Rautahi, London: Routledge and Kegan Paul.

Metge, J. 1986 In and Out of Touch: Whakamaa in Cross Cultural Context, Wellington: Victoria University Press

Metge, J. 2001 Korero Tahi: Talking Together, Auckland: Auckland University Press.

Moon, P. and S. Fenton 2002 Bound into a Fateful Union: Henry Williams' translation of the Treaty of Waitangi into Maori in February 1840, Journal of the Polynesian Society 111: 51-63.

Mutu, M. 1992, Tuku Whenua or Land Sale, 24 April 1992 (Draft); Submission to Waitangi Tribunal's Muriwhenua Land Claims, Doc. F 12.

Ngata, Sir A. 1922 (1963) The Treaty of Waitangi: An Explanation (translated by M.R. Jones), Wellington.

Orange, C. 1987 The Treaty of Waitangi, Wellington: Bridget Williams Books.

Ortega y Gasset, J. 1937 (2000) The Misery and the Splendor of Translation, in (pp.49-63) Lawrence Venuti (ed.) The Translation Studies Reader, London: Routledge.

Ortega y Gasset, J. 1959 ‘The Difficulty of Reading', Diogenes 28: 1-17.

Reddy, M. 1979 The Conduit Metaphor, in (pp. 284-310) A. Ortony (ed.), Metaphor and Thought, Cambridge: Cambridge University Press.

Robinson, D. 1997 Becoming a Translator, London: Routledge.

Ross, R. 1972 'Te Tiriti o Waitangi: texts and translations', New Zealand Journal of History 6: 129-57.

Samuels, W. 1990 Economics as Discourse: An Analysis of the Language of Economists, Boston: Kluwer Academic

Sharp, A. 1990 Justice and the Maori, Auckland: Oxford University Press 
Steiner, G. 1975 After Babel: Aspects of Language and Translation, London: Oxford University Press.

Tribe, L. and M. Dorf 1991 On Reading the Constitution, Cambridge Mass.: Harvard University Press

White, J. 1990 Justice as Translation, Chicago, University of Chicago Press.

Williams, D. 1989 Te Tiriti o Waitangi - Unique Relationship Between Crown and Tangata Whenua?, in I. Kawharu (ed), Waitangi: Maori \& Pakeha Perspectives of the Treaty of Waitangi, Auckland: Oxford University Press.

Winter, S. 2001 A Clearing in the Forest: Law, Life, and Mind, Chicago: University of Chicago Press 